\title{
DOES THE DEVELOPMENT OF NON-CASH PAYMENTS AFFECT BANK LENDING?
}

\author{
Santiago Carbó Valverde* \\ University of Granada and Federal Reserve Bank of Chicago
}

\section{Rafael López del Paso}

Economist

\begin{abstract}
Previous studies show that the impact of an exogenous monetary policy shock on bank lending is different across bank sizes and across various levels of capitalization and liquidity. However, there is little evidence on the impact of other exogenous influences such as the shift from cash- to non-cash payment instruments on bank lending. The shift to electronic payments significantly alters bank balance sheets and consumer liquidity restrictions and, therefore, it is likely to affect bank lending decisions. This paper explores the effects of the increasing use of non-cash payments instruments on bank lending in Spain during 1992-2000. The results show that banks appear to have taken advantage of the non-cash instruments to adjust their loan supply when interest rates increase (120 words).
\end{abstract}

Key words: bank lending, non-cash payments

JEL codes: E51, G21, O33

*Corresponding author: Santiago Carbó Valverde, Departamento de Teoría e Historia Económica. Facultad de Ciencias Económicas y Empresariales. Universidad de Granada. Campus Universitario de Cartuja s/n. 18071 Granada, Spain. +34 958243717. scarbo@ugr.es

Acknowledgements: Financial support from MEC-FEDER, SEJ2005-04927 are acknowledged and appreciated by the authors. Santiago Carbó also acknowledges financial support from Junta de Andalucia, SEJ 693 (Excellence Groups). The views in this paper are those of the authors and may not represent the views of the Federal Reserve Bank of Chicago or the Federal Reserve System. 


\section{Introduction}

Previous studies have provided evidence that bank lending and the effects of monetary policy shocks are significantly different across bank sizes and various bank levels of capitalization or liquidity (Kashyap and Stein, 2000, Kishan and Opiela, 2000) ${ }^{1}$. Along with these influences, the observed shift from cash- to non-cash payment instruments all over the world is significantly altering bank balance sheets and consumer liquidity restrictions and, therefore, it is likely to affect bank lending decisions as well. However, very few studies have looked at the impact of payment systems development on bank lending. This relationship also has important implications for monetary policy and for the bank lending channel. In particular, in the case of the European Monetary Union (EMU), our study has implications for the implementation of a Single European Payments Area (SEPA) -to be fully implemented at the beginning of 2011-, which involves the creation of a zone for the euro in which all electronic payments are deemed as domestic and where a difference between national and intra-European cross-border payments does not exist. However, in spite these payment convergence efforts for EMU, there have been in the past and there still are many differences in the retail payment area in the EMU (European Central Bank, 2003).

Both cash and non-cash instruments are used by consumer and business to facilitate the purchase of goods and services. Consumers hold an inventory of cash which is drawn down over time to make purchases, businesses hold cash to make change for cash purchases, and banks hold vault cash for re-supplying these inventories either through ATMs or at branch offices. These cash holdings, part of which are the reserves required by the central bank, are not available for banks to make loans or purchase securities since they are employed in the daily liquidity payments (i.e. deposit withdrawals). In the loan context, these cash holdings are an "idle asset" in the banking system. In contrast, non-cash payment instruments -debit and credit cards, cheques, direct debits, credit transfers- are a substitute

\footnotetext{
${ }^{1}$ The bank lending channel focuses on the possible effects of monetary policy actions on the supply of bank loans. It only works when deposits and bonds are imperfect substitutes in the balance sheet of banks. In this case, following a reduction in liquidity, banks cannot turn freely to the bond market, due the external finance premium. Then, they must reduce the amount of loans they supply and/or further increase the interest rate they charge for loans, thus amplifying the initial effects of the monetary policy tightening (Bernanke and Blinder, 1992).
} 
method for making payments by consumers and businesses but the assets they debit are not idle -they are held as deposits and used by banks to make loans or purchase securities. Other things being equal, as the share of payments shifts from cash to non-cash instruments, loanable funds in the banking system rises. This may, in turn, affect the availability of loanable funds and, hence, economic activity (Drehmann et al., 2002). While this occurs slowly over time and will typically be in the same direction -that is, it is unusual to see a significant shift away from non-cash instruments- it does mean that the sensitivity of economic activity to changes in loan supply is not stable but is a function, inter alia, of the development of the payment system. Such a modification of the operability of bank lending necessarily influences the design and effectiveness of monetary policy (Bernanke and Blinder, 1992; Bernanke and Gertler, 1995). For this reason, in establishing its strategy of monetary policy, central banks should carefully assess to what extent the banks operating in each member country have taken advantage of the development of payment systems — not only to improve payment services, but also to keep the clients' financial needs covered, even when the measures adopted are meant to reduce lending ${ }^{2}$.

This paper analyzes the evolution of bank lending supply in Spain during 1992-2000 and attempts to assess the effects of non-cash payments on this lending behaviour. The study borrows from a baseline bank lending channel equation and analyses how loan supply varies when the shift from cash to non-cash payments is controlled for. It should be noted, however, that the focus is on the effects of changes in the use of payment instruments on the loan supply conditions while any hypothetical direct relationship between non-cash payments and monetary policy (via changes in interest rates) is not considered or tested. Spain is a unique laboratory to undertake the empirical study for two main reasons: 1) its strong roots in cash payments and the subsequent and considerable development of electronic payments (European Central Bank, 2001); and 2) the significant dependence of households and firms investment and consumption decisions on bank lending (Bank of Spain, 2002).

\footnotetext{
${ }^{2}$ When referring to lending decisions and monetary policy, this article follows the financial market price view of the monetary transmission mechanism, and specifically, the bank lending channel. This election does not imply
} 
Our analysis proceeds as follows. Section 2 offers a survey of previous evidence in the relevant literature on bank-lending channel and the effects of changes in payment methods on bank loan supply. In Section 3 a theoretical model is developed to show how the evolution of the retail payment system can affect the bank loan supply. On the basis of these relationships, Section 4 describes the empirical methodology and data employed to estimate the magnitude of this impact over the period 1992-2000. Section 5 presents the main results while the conclusions are drawn in Section 6.

\section{Relevant background}

\subsection{Evidence on the bank-lending channel: effects of changes in payment systems}

According to the theory of the bank-lending channel, tight monetary conditions lead to an increase in market interest rates. The consequently higher cost of deposits - the main financial source of banks - can lead to a reduction in bank loan supply (Bernanke and Blinder, 1988; Gertler, 1988; Kashyap and Stein, 1994). The extent of this reduction will depend, at least, partially on i) the price elasticity of money demand and, therefore, on the balance sheet structure of financial institutions; and ii) the financial literacy of users, as well as their habits and preferences for payment instruments (Goodfried, 1995).

Relationships between loan supply and money demand have only been considered indirectly by analysing the effects of certain non-cash payment instruments (mainly credit cards) on money demand. The seminal study of Ausubel (1991) illustrates that consumer credit interest rates remained sticky at such a high level in the United States due to the presence of supernormal profits and some competition failures in the credit card market. Similarly, Brito and Hartley (1995) suggest that consumers increasingly carry out credit (or differed debit) card payment transactions since obtaining relatively low-interest credit involves higher transaction costs. Calem and Mester (1995) also argue that consumers' reluctance to search for lower rates can be explained by high search costs in this

that other monetary transmission mechanisms, as the interest rate and the balance sheet channel can not operate in this context. 
market. Cargill and Wendel (1996) suggests that due to the high presence of convenience users, even modest search costs could keep the majority of consumers from seeking out lower interest rates from bank loans. Similarly, Attanasio et al. (2004) offer related support for liquidity-constraints in consumer credit markets. Gross and Souleles (2002) utilize a unique new dataset of credit card accounts to analyze how cardholders respond to changes in credit supply. They find that increases in credit limits generate an immediate and significant rise in debt, consistent with the buffer-stock models of precautionary saving (Deaton, 1991; Carroll, 1992, and Ludvigson, 1999). Although these studies do not directly examine the effect of non-cash payment instruments on loan supply, they illustrate two important mechanisms through which this relationship may be important: i) changes in money demand and liquidity constraints as a consequence of the use of the credit facilities of some of these payment instruments (e.g. credit cards); ii) changes in searching costs and convenience that increase the willingness to assume higher interest rates for payment instruments that offer credit facilities and move illiquid consumption restriction forward in time. These studies, along with the descriptive consumer credit statistics, give credit to the importance of consumer lending for the bank lending channel and to the effects of payment.

In order to appropriately consider the effect of non-cash payment instrument in bank lending, any empirical approach should also include the standard set of bank-level influences that may affect loan supply and the bank lending channel. Variables such as size, bank capitalization and liquidity are used in the literature to approach the differential and distributive effects of monetary shocks on loan supply ${ }^{3}$. In the literature these variables are included in several European studies that challenge the validity of the bank lending channel hypothesis ${ }^{4}$. For instance, Favero et al. (1999) do not obtain favourable evidence of the bank- lending channel theory in their cross-sectional sample of German, Italian and Spanish banks in 1992. However, they demonstrate the existence of substantial differences in the means through which the financial institutions of each country try to maintain their loan supply

\footnotetext{
${ }^{3}$ See, for example, Diamond (1984), Kashyap and Stein (1995), Stein (1998) and Kashyap and Stein (2000) for further details of the way in which these variables operate in this theoretical framework.

${ }^{4}$ Most of these studies rely on statistics from the international database Bankscope, which suffers from important deficiencies in comparison with the statistical series provided by national Central Banks (Ehrman et al., 2003).
} 
in the advent of a monetary tightening. Whereas the smaller institutions of these three countries resort to attracting new deposits, the French banks use the "buffer" of capital. Altunbas et al. (2002) study loan behaviour in the European Monetary Union and show that the loan supply of the least capitalized banks is frequently more sensitive to variations in market rates. They also find favourable evidence for the lending channel among the less solvent banks operating in the smallest countries of the European Union. Considering cross-country comparisons, it appears that the validity of the bank-lending channel is only confirmed for Spain and Italy.

Ehrmann et al. (2003) demonstrate that an increase in the monetary policy interest generates a substantial tightening in bank loan supply within the EMU. These authors point out that, unlike in the United States, the differences in bank size or in the degree of bank capitalization and liquidity do not give rise to significant distributive effects in the European context. Among the explanations to this finding there are various important factors such as the relatively minor problems of asymmetric information due to greater government control, the presence of bank networks, the low number of bank crises, and other aspects such as the degree of financial market integration or the intensification of competition (Cottarelli and Kourelis, 1994; Fase and de Bondt, 2000; Sellon 2002). A cross-country study by Ehrmann et al. (2003) suggest that size -as a proxy of the degree of informational asymmetries- plays a significant role only in the case of Spain. In these studies the level of capitalization does not appear to be relevant while liquidity gives rise to distributive effects in Italy, Germany and Spain.

\subsection{Recent trends in European payment systems and their relevance for bank- lending}

In consonance with the rest of the European countries, the Spanish payment system has experienced a sharp transformation as a consequence of the technological developments in banking activities. The intensification of competition and the continuous reductions of interest rates during the second half of the 1990s narrowed bank margins and led financial intermediaries to reconsider their operative strategies. For this reason banks opted to expand their traditional intermediation activities towards financial innovations (mainly through off-balance sheet activities) and improve operative 
efficiency. Branches have been largely replaced by ATMs, and non-cash payment instruments have become widespread; and the lower cost and higher convenience of electronic instruments is changing the configuration of the payment system.

In recent years, the traditionally higher use of cash in payments in Spain has been compatible with a certain modernization of payment habits. However, some differences remain in various of the most advanced national payment systems of the EMU. Over 1992-2000, the relative weight of cash transactions - proxied by the value of banknotes and coins as a percentage of GDP- was greater in Spain than in EMU (Table 1). Although Spain relies relatively heavily on cash to make payments compared to EMU countries, the use of cash has apparently fallen more markedly in Spain. As a result, the growth rate of non-cash payment instruments is clearly higher in Spain (47.23\%) than in EMU (19.14\%) over 1992-20005.

As far as banking activities are concerned, loans (as a percentage of GDP) grew in Spain at a higher rate than in EMU (72 and 35\%, respectively during 1992-2000). The growth of the deposit base (as a percentage of GDP) was lower in Spain (31\%) than in EMU (38\%). This increase in bank business has been compatible with a fall in the average operating cost per asset during the sample period: $-37 \%$ for Spain and $-15 \%$ for EMU. The reduction in operating costs has been mainly motivated by the more intensive use of ATMs and electronic payments (Carbó Valverde et al. 2007).

A tentative hypothesis from these trends may be that the development of the Spain's retail payment system has contributed to increasing banks' deposit base, and thereby to expanding their loan supply, even when a monetary tightening takes place. Nonetheless, a theoretical framework may more clearly illustrate these relationships and give support to the empirical estimations.

\footnotetext{
${ }^{5}$ If, instead of looking at the values, we look at the number of transactions, the differences shown by Spain with regard to EMU are not so large, which shows that the average value of the transactions with the electronic payments in Spain is comparatively lower. Therefore, these instruments are largely diffused in Spain but they have not reached, quantitatively, the degree of development (in total value) evidenced in the EMU.
} 


\section{A theoretical model}

We now design a model in which the evolution of the retail payment system alters bank lending decisions in a baseline bank-lending channel framework. This involves the introduction of non-cash payments in the bank loan supply relationship along with monetary conditions. The basic reference is the model specified by Peek and Rosengren (1995) and explicitly relies solely on a linear specification of loan supply. We also assume that banks employ both asset and liability management to a significant extent to adjust to exogenous changes in monetary policy ${ }^{6}$. We incorporate three ingredients to this model: i) the potentially expansive effect of the diffusion of non-cash payments and the use of the ATMs upon bank deposits, and finally upon bank loan supply ${ }^{7}$; ii) banks' reliance on the interbank market for the necessary resources to resolve restrictions of liquidity deriving from a tightening of monetary conditions; and iii) the costs associated with the development of this activity.

We present a model of bank $i$ in period $t$ which is assumed to have three assets: required reserves ( $r r)$, liquid assets (liq) and loans (loan); and three liabilities: net interbank deposits $(d d)$, deposits funding (dep) and capital (cap); The balance sheet constraints require:

$$
r r+l i q+l o a n=d d+d e p+c a p
$$

$d d$ are assumed to be inversely related to the market interest rate $\left(i_{0}\right)$ :

$$
d d=a_{0}-a_{1} i_{0}
$$

A bank is assumed to have market power in the dep market, and can, therefore, raise dep by increasing its rate $\left(i_{D E P}\right)$ above the mean market rate $\left(i{ }_{D E P}\right)$. The deposits base also increases with the value of transactions with non-cash instruments (pay). This can be derived both from the increase of the opportunity cost of holding $\operatorname{cash}^{8}$, and the greater convenience that the consumers experienced regarding the use of non-cash instruments (Paroush and Ruthenberg, 1986; Schneider, 1986; Zilberfarb, 1989). Thus:

\footnotetext{
${ }^{6}$ While asset management may imply changes in the composition but not necessarily in the total amount of lending, liability management permits net changes in bank lending and, therefore, seems to be more related to the rationale for a bank-lending channel.

${ }^{7}$ The use of ATMs is frequently considered as compatible with the substitution of cash for non-cash payments. In particular, ATM machines are employed by banks to move some basic customers' transactions away from branches. For these reasons, it is not surprising that banks simultaneously deploy ATMs and point-of-sale machines to promote non-cash payment instruments (see, for example, Rysman, 2007).
} 


$$
d e p=b_{0}+b_{1}\left(i_{D E P}-i_{D E P}^{*}\right)+b_{2} p a y
$$

In agreement with the most recent developments in monetary theory the value attained by pay depends positively on the income level ( $g d p)$ and prices (cpi), as well as on average market deposit rate $\left(i{ }_{D E P}\right)$ (Humphrey, Kaloudis and Owre, 2004), that is:

$$
\text { pay }=c_{0}+c_{1} g d p+c_{2} c p i+c_{3} i_{D E P}^{*}
$$

Banks hold a fraction $(\alpha)$ of $d d$ in liquid reserves $r r$ to face daily operations and fulfil requirements established by supervisory authorities ${ }^{9}$, by which:

$$
r r=\alpha d d
$$

Given this restriction and assuming that the liquid assets are proportional to $d d$, these would be given by:

$$
l i q=d_{0}+d_{1} d d-r r
$$

Banks' loan supply would depend on deposits funding, and on the sale of liquid assets and/or resources from the interbank market when the former are insufficient ${ }^{10}$. The market for bank loans is assumed to be imperfectly competitive ${ }^{11}$. Individual banks can increase (decrease) loans by moving their rates $\left(i_{L O A N}\right)$ below (above) the mean market rate $\left(i{ }^{*}{ }_{L O A N}\right)$. Consequently:

$$
\text { loan }=e_{0}+e_{1} d e p+e_{2} l i q+e_{3} d d-e_{4}\left(i_{L O A N}-i_{L O A N}^{*}\right)
$$

\footnotetext{
${ }^{8}$ Thus, our model only implicitly considers cash holdings but confer them a great deal of importance in the context of expansion of interest-bearing and highly liquid deposit accounts.

${ }^{9}$ For simplicity, we assume that liquidity requirements by supervisory authorities are managed by banks together (and as a function) of their daily operations and net position in the interbank market. The interbank net position, however, is explicitly linked in our setting to deposit holdings so that liquidity management and requirements can be assessed on a homogenous basis.

${ }^{10}$ Credit may be understood from a traditional intermediation perspective (only loans) or alternatively in a wider sense, where the measure of credit includes loans plus loan commitments.

${ }^{11}$ The assumption of imperfectly loan and deposits markets is a common feature in these theoretical (Peek and Rosengren, 1995) and empirical approaches (as Hernando and Martínez-Pagés, 2003, for evidence for Spain).
} 
The mean market rates $\left(i_{D E P}, i^{*}{ }_{L O A N}\right.$, and $\left.i^{*}{ }_{L I Q},\right)$ with spread are fixed after establishing an intermediation margin $\left(\phi_{j}\right)$ over the monetary policy interest rate $\left(i_{0}\right)^{12}$ :

$$
\begin{aligned}
& i_{D E P}^{*}=f_{0}+\phi_{1} i_{0} \\
& i_{L O A N}^{*}=g_{0}+\phi_{2} i_{0} \\
& i_{L I Q}^{*}=h_{0}+\phi_{3} i_{0}
\end{aligned}
$$

Banks are assumed to maximize profits $(\Pi)$,

$$
\Pi=\operatorname{loan}\left(i_{L O A N}-\Phi\right)+\operatorname{liq} \cdot i_{L I Q}-d d \cdot i_{0}-\operatorname{dep} \cdot i_{D E P}-C
$$

Profits include the interest income on loans $\left(\right.$ loan $\left.\cdot i_{L O A N}\right)$ net of loan loses $(\Phi \cdot l o a n)$, and the interest on liquid assets $\left(l i q \cdot i_{L I Q}\right)$, minus the interest paid on interbank market $\left(d d \cdot i_{0}\right)$, and non-bank deposits $\left(d e p \cdot i_{D E P}\right)$, and minus operating costs $(C)$.

Substituting (2), (3), (6), (7), (8), (9), (10) in (11), and partially deriving with respect to the monetary policy interest rate, as well as the loan rate, the deposits rate, and the price of liquid assets, we obtain the following first order conditions:

$$
\begin{aligned}
& \partial \Pi / \partial i_{0} \partial i_{L O A N}=\phi_{1} e_{1}\left(b_{2} c_{3}-b_{1}\right)-e_{3} a_{1}+e_{2} a_{1}\left(\alpha-d_{1}\right)+\phi_{2} e_{4} \\
& \partial \Pi / \partial i_{0} \partial i_{D E P}=\phi_{1}\left(b_{1}-b_{2} c_{3}\right) \\
& \partial \Pi / \partial i_{0} \partial i_{L I Q}=\left(\alpha-d_{1}\right) a_{1}
\end{aligned}
$$

From equation (12), we deduce that the impact of a change in the monetary policy interest rate on a bank loan rate will be larger when: 1) the market power is lower $\left(b_{1}\right)$, and 2) the volume of transactions with non-cash instruments is greater $\left(b_{2}\right)$. The magnitude of the latter will depend on the average market deposit rate $\left(c_{3}\right)$, which is deemed as the opportunity cost of the deposits. The magnitude of the impact will also depend on the requirements of liquid reserves $(\alpha)$ to which the bank is subject.

\footnotetext{
${ }^{12}$ Unlike Kishan and Opiela (2000), we do not assume the margin set for the market rate on loans, deposits and
} 
As expected (equation 13), an increase in the market rate on the part of the Central Bank has a negative impact on the bank's profits, and even more so when: 1) the bank market power is lower $\left(b_{1}\right)$; and 2) the opportunity cost for users of bank services to hold balances for payment purposes is higher $\left(b_{2}\right)$.

Consequently, and based on the results obtained for a representative bank (equations 12 to 14), we find that the greater value of the operations using non-cash instruments, the lower the tightening of the loan supply. At the same time, the bank-lending channel theory indicates the degree to which these distributive effects are manifested will also depend on the size of the bank, the proxy variable of the market power, and the degree of solvency and liquidity.

\section{Empirical approximation and data}

\subsection{Specification and definition of variables}

The general equation to be estimated is given by ${ }^{13}$ :

$$
\begin{aligned}
& \Delta \log L_{i t}=\alpha_{i}+\sum_{j=1}^{4} \beta_{j} \Delta \log L_{i(t-j)}+\sum_{j=1}^{4} \chi_{j}\left(b c_{i(t-j)} \cdot \Delta m p i_{t-j}\right)+ \\
& +\sum_{j=0}^{4} \delta_{j} \Delta m p i_{(t-j)}+\sum_{j=0}^{4} \phi_{j} \Delta z_{i(t-j)}+\varphi \Delta p a y+\gamma \Delta p a y \cdot b c_{i t}+d_{t}+\varepsilon_{i t}
\end{aligned}
$$

where, $L$ shows means of loan supply; mpi represents the interest rate indicator of monetary policy; $b c$ is a vector denoting the bank characteristics considered; $z$ is the matrix of macroeconomic variables; pay shows a proxy of the development of the payment system at each point in time $t$; and $\Delta$,

liquid assets to be the same, as the costs of each activity may differ.

${ }^{13}$ Although the use of these specifications to reflect variation over time may be preferable to the VAR model and cross-section estimation, they have their limitations as well, and results must always be interpreted with care (Bond, 2002). Firstly, they do not permit a perfect identification of the relevant structural parameters that confirm the validity of the bank-lending channel as specified by Bernanke and Blinder (1988). Furthermore, a bias may be introduced by using variables with a solely temporal dimension, fundamentally the macroeconomic variables. Finally, by considering the variables in first differences, it is not possible to take into account possible relations of balance items derived from the theoretical model. 
$d$ and $\varepsilon$ are respectively identified as the operator difference, the vector of dummy time variables, and the error term. Finally, $\alpha$ symbolizes the fixed specific effect of each entity $i^{14}$.

Given the limitations of the public information, the definitions used for $L$ are total loans (loan), and "total loans plus loan commitments" (loancom $)^{15}$. By including the latter, we have: 1) the "buffering effect" of loan commitments, which can neutralize the contraction of the traditional loans supply (Morgan, 1998); and 2) the impact of product financial innovation on the bank loan supply. The indicator of monetary policy used was the three-month interbank interest rate (Kashyap and Stein, 2000; Kishan and Opiela, 2000).

We also consider the size, the degree of capitalization and liquidity of the banks. All bank-specific variables are demeaned which results in the sum of all included observations being equal to zero. This guarantees that the $\chi^{\prime}$ s in (15) are not influenced by the level effect of $\Delta m p i$ on $\Delta L_{i t}$, and can be directly interpreted as the average monetary policy effects (Worms, 2003).

Size $(t a)$ is defined as the difference between the value of the total assets $(A)$ of each bank $i$ in period $t$, and the mean value for each one of the periods of observation corresponding to the set of banks comprising the sample, that is:

$$
t a_{i t}=\log A_{i t}-\left[1 / N \sum_{i=1}^{N} A_{i t}\right]
$$

This process removes unwanted trends in size (namely, those trends resulting from the fact that size is measured in nominal terms).

The proxy variables of the degree of capitalization and liquidity are determined- as they are defined in ratios- by subtracting from the value of each observation the arithmetic mean of the total

\footnotetext{
${ }^{14}$ In order to obtain a random walk, four lags were incorporated; this number was found to minimize residuals, after trials with 1 to 12 lags. Since these variables are non-stationary, as verified by the Dickey Fuller test, they are considered in first differences.

${ }^{15}$ The public information available does not disaggregate between different types of lending.
} 
sample $^{16}$. In this way, its variability is guaranteed over time. Hence, the variable degree of capitalization (cap) is defined as:

$$
\operatorname{cap}_{i t}=K_{i t} / A_{i t}-\left[1 / T \sum_{t=1}^{T} 1 / N \sum_{i=1}^{N} K_{i t} / A_{i t}\right]
$$

where $K$ means the sum of Tier 1 and Tier 2 regulatory capital.

The variable of degree of liquidity $(l i q)$ is constructed similarly, representing the relative weight of the liquid assets (LA) in terms of total assets (Mishra, 2004):

$$
l i q_{i t}=L A_{i t} / A_{i t}-\left[1 / T \sum_{t=1}^{T} 1 / N \sum_{i=1}^{N} L A_{i t} / A_{i t}\right]
$$

Our definition of liq is given by the sum of cash and deposits in Central Banks, net interbank deposits, Government bonds and other securities, divided by total assets.

The macroeconomic variables included in matrix $z$ have been selected according to their relevance for the loan demand (Fase, 1995). As it can be found elsewhere in the related literature, these macro variables proxy changes in business cycle and environmental conditions (Kashyap and Stein, 2000; Kishan and Opiela, 2000). These variables are the logarithm of Gross Domestic Product ( $g d p)$, Consumer Price Index (cpi) and the level of risk assumed at bank level (risk), all expressed in bankspecific terms. This means that, the $g d p$ variable is defined as the weighted GDP of different regions of Spain $k$ (Comunidades Autónomas) where the bank operates. The weighting factor is the number of branches each bank has in each region $\left(S^{k}\right)$ with respect to its total network of branches $(S)$; that is ${ }^{17,18}$ :

$$
g d p_{i t}=\sum_{k=1}^{18}\left(S_{i t}^{k} / S_{i t} \cdot g d p_{t}^{k}\right)
$$

Similarly, the Consumer Price Index, $c p i$, is given by:

\footnotetext{
16 See Mishra (2004) for a comprehensive analysis on the methodological advantages of using a weighted arithmetic mean of all sample observations.

17 The regions considered are the 17 Comunidades Autónomas of Spain, and the two Spanish Territories in Africa (Ceuta and Melilla).

${ }^{18}$ By considering the map of regional information as a weight, we attempt to capture: 1) the diversity of economic, social and institutional conditions, determinant factors for the added value generated in the territories
} 


$$
c p i_{i t}=\sum_{k=1}^{18}\left(S_{i t}^{k} / S_{i t} \cdot c p i_{t}^{k}\right)
$$

Finally, the level of risk (risk) is given by the logarithm of the net provisions for risk and insolvency $^{19}$. Although this indicator constitutes an ex post measure of risk, it stands as a good proxy of the level of risk of the bank, as it takes in both the materialized risk (via the component of reserves) and that anticipated (through provisions) (Ho and Saunders, 1981; Borio et al., 2001) ${ }^{20}$. If the default risk of the loan portfolio increases, banks may increase loans in order to both enable firms to solve their liquidity problems and to meet a possible increase in loan demand. Therefore, the sign of the risk variable should be negative.

The expansive effect of the development of the retail non-cash payment system on deposit demand has been traditionally quantified by the number of credit cards issues, or the number of operations involving credit cards, giros or cheques. The use of these indicators may give rise to measurement errors since they do not represent development reached by the payment system but rather its diffusion and state (Viren, 1992). To solve this problem, the value of the operations with non-cash payment instruments (noncashvalue) is divided by the aggregate value of all payments (allpayvalue) - value of non-cash payments plus approximate value of cash payments (Humphrey, 2004) ${ }^{21}$.

$$
\text { noncash }=\text { noncashvalue/allpayvalue }
$$

\footnotetext{
where they operate; 2) the response of the banks to the economic environment, as opening new branches is very often determined by economic dynamics rather than by strategic decisions (Jarayatne and Strahan, 1996).

${ }^{19}$ The public information available does not allow us to obtain ex ante measures of risk. Moreover, given that the values of these items can be negative, they are taken as absolute values. Once logarithms are applied, the previous sign is considered. In this way there is no loss of observations as a result of changes in the scale of the variable.

${ }^{20}$ Note that the inclusion of this variable may imply an underestimation of the possible effects of monetary policy on the bank loan supply through the terms of interaction. However, according to the literature, it is assumed that the impact of monetary policy on risk is less important than the influence of exogenous changes in the probability of credit default (Worms, 2003).

${ }^{21}$ We have estimated the value of cash as follows. From the Total Consumption reported in the National Accounts, we substract some items that are not paid by cash, which gives the point-of-sales value we use (POSsale). Subtracting the value of check, card and giro payments from POSsales gives an estimate of cash payments value at the retail side.
} 


\subsection{Methodology and data}

Equation (15) is estimated following the specifications defined in the above section. We define the following main empirical model:

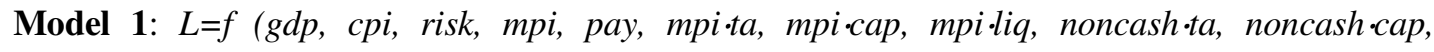
noncash $\cdot(\mathrm{liq})$

The regression analysis is performed taking as the dependent variable loan and loancom (loans and loan commitments) ${ }^{22}$. We also introduce the three main banks' characteristics altogether: size, liquidity and capitalization. These characteristics are not independent from each other and including them separately in a model is likely to generate an omitted variable bias.

In order to test the robustness of the results to different specifications, the Appendix A presents a set of alternative models ( 2 to 4$)$ :

Model 2: $L=f(g d p, c p i$, risk, mpi, noncash, mpi·ta, noncash ·ta)

Model 3: $L=f(g d p, c p i$, risk, mpi, noncash, mpi cap, noncash·cap)

Model 4: $L=f(g d p$, cpi, risk, mpi, pay, mpi $\cdot$ liq, noncash $\cdot l i q)$

We estimate these models employing dynamic panel data techniques ${ }^{23}$. More specifically, we use the GMM estimator of Arellano and Bover (1995) and Blundell and Bond (1998), in view of its capacity to reduce inaccuracies and estimation bias, potentially resulting from the inclusion in the specification of lags of the dependent variable. This estimator is based on the simultaneous estimation of two equations. The first is the regression of equation (15) in differences, while the second refers to its estimation in levels. By applying both, we obtain consistent and efficient estimations provided that

\footnotetext{
${ }^{22}$ Equation (15) is not estimated including a triple term of interaction made up of two bank characteristics and noncash, since in this case, we would not be employing adequate instruments (Arellano and Bond, 1991).

23 This procedure has important advantages over simple cross-section OLS and other estimation methods (Arellano and Bover, 1995). First, the GMM procedure significantly reduces the estimation bias from omitted variables by controlling for unobserved bank-specific or "fixed" effects. Secondly, the use of instrumental variables allows a consistent estimation in models that contains endogenous right-hand side variables, such as non-cash payments.
} 
the instruments are adequate in terms of the properties of serial correlation of the model. Therefore, the instruments are, along with the lagged dependent variable ( 2 to 5 lags), the variables of the matrix $z$ (1 to 5 lags), those relative to the bank characteristics ( 1 to 5 lags) and of the development of the payment system (1 lag), as well as those corresponding to the terms of interaction of the latter two groups of variables with the indicator of monetary policy (1 to 5 lags $)^{24}$.

It is assumed that the loan reaction of each bank depends lineally upon $b c$, which varies just as much from one bank to the next as it does over time. This linear dependence is accounted for by the terms of interaction $b c_{n, t-j} \cdot m p i^{25}$. Then, under the assumption that the loan demand is homogeneous with respect to its interest rate elasticity for each bank, the interaction coefficient can be interpreted as the degree of heterogeneity of loan supply responses across banks. Moreover, by including $b c$ we foresee the possible direct effects of this variable on the loan growth index $L$, already captured by the coefficients $\chi$. In this way, the long-term coefficients $(\eta)$ are given as the sum of the coefficients on the explanatory variable $(\Phi)$ divided by one minus the sum of the coefficients on the lagged dependent variable $(\beta)$, that is:

$$
\eta=\frac{\sum_{i=0}^{3} \Phi_{i}}{1-\sum_{i=1}^{3} \beta_{i}}
$$

These long-term coefficients represent the distributive effects (differential impact) on loan supply, provided that the rest of the variables incorporated into the specification account adequately for the variations caused by the loan demand ${ }^{26}$. Hence, when the long-term estimated coefficients of the

\footnotetext{
${ }^{24}$ The appropriateness of the instruments is tested using the Sargan test for overidentifying restrictions.

${ }^{25}$ In order to demonstrate the possible endogeneity between size, degree of liquidity or capitalization and the economic cycle indicators, equation (15) is estimated introducing additional terms combining each bank characteristic with $g d p$ and $c p i$. The results are very similar, but they are not reported in this paper to simplify the analysis. Similarly the temporal variation was completely eliminated from the specification. The three variables (mpi, gdp y cpi) whose dimension is time-dependent are adequate for gathering the relevant temporal effects.

${ }^{26}$ The calculation of the long-term coefficients is employed for several reasons. First, they have a greater capacity of identification of trends. Secondly, their use avoids error in the interpretation of results due to the possibly alternating signs of the short-term coefficients with respect to the lag. Finally, their economic robustness and sensitivity are greater.
} 
interaction parameters are not statistically different from zero, it cannot be accepted that there exists a differentiated response on the part of the loan supply among the different banks.

Given the problems generated by the use of macroeconomic data in identifying variations in the loan supply caused by changes in monetary policy (Kashyap and Stein, 2000), we employ quarterly micro data for the period $1992-2000^{27}$. The individual banks' data (taken from their public balance sheets) have been converted into seasonally adjusted series undertaking the X-11 ARIMA procedure (Hyllerberg, 1992; Alvarez, 1999) ${ }^{28}$. As for the retail payment system variables, as there is no public information available for individual banks, we used aggregate data provided by the Blue Book of the $\mathrm{ECB}^{29}$. Their use is adequate because the objective of the present study is to analyse to what extent the development of the payment system has helped banks expand their deposit demand, and in turn, their loan supply.

The sample includes 176 commercial and savings banks representing over $95 \%$ of total assets of the banking sector in the period. As for mergers we use the backward aggregation methodology by summing up the balance sheet items of the merging banks -as if they had been always a single bankeven before the merger took place. This procedure restricts the individual effects of the merging banks to the same value over the entire period and allows us to employ a balanced panel of banks. This procedure is particularly adequate when banks merge in order to reduce costs by increasing size (Lang and Welzel, 1999) ${ }^{30}$.

\footnotetext{
${ }^{27}$ This time horizon is especially interesting in view of the events taking place in the European context and within the Spanish economy. On top of the economic recession of 1992-1994, other big events were the liberalization of the movement of capital in 1993, the compromise by the European nations in 1996 to reach convergence in the main macroeconomic aggregates, the creation of the single currency, and intense financial innovation and liberalization. During this period the Spanish payment system also reached a high point in its development. Moreover, from this temporal horizon homogeneous information can be obtained on the balance sheet and income statement of the banks and about the payment system.

${ }^{28}$ This adjustment is advisable for several reasons: 1) the presence of individual seasonal effects increases the error term of the orthogonal conditions corresponding to the equation in differences from which the GMM estimation is made; 2) The coefficients of the explanatory variables that do not vary over time may or may not be identified, depending on the assumptions established with regard to the random effects.

${ }^{29}$ As the data provided by the ECB are annual, we generated quarterly data -to amplify the frecuence of the data- by applying an ARIMA model $(1,0,1)$ (Boeschoten, 1992).

${ }^{30}$ We also followed alternative assumptions as to eliminate merging institutions from the sample or directly employing an unbalanced panel of banks and the results were similar. These results are not shown for simplicity (available upon request).
} 


\section{Empirical evidence}

The results corresponding to the long-term coefficients of the complete model (Model 1) are shown in Table $2^{31}$. Table A1 (in the Appendix A) displays the results when loan is employed as dependent variable, and Table A2 includes the results for loancom as dependent variable ${ }^{32,33}$.

The development of the non-cash payments in Spain appears to have been utilised by banks to increase their supply of loans and of loan commitments. As for the narrow definition of credit, the coefficient of the non-cash variables is .219 and statistically significant at 5 per cent. The magnitude of this effect is slightly higher (.281) when the dependent variable is loans plus loans commitments. The higher use of low-cost electronic payments appears to have resulted in a larger base of intermediated resources. In this fashion, Spanish banks have taken advantage of the relative benefits in terms of cost, security and convenience of the ATM, credit card and giro use, enhancing at the same time the level of efficiency in channeling economic resources ${ }^{34}$.

The impact of this development on banks' business depends largely on the structure of banks' balance sheet. This impact can be observed through the analysis of the coefficients of interaction of the variable representing the development of non-cash payments in Spain, and for each of the bank characteristics. They show that the larger banks (having a greater proportion of liquid assets), followed

\footnotetext{
${ }^{31}$ Additionally, the analysis was undertaken for the deposit demand. The results show the impact of monetary tightening to be limited. The distributive effects appear not to be motivated by differences in size, or by the level of capitalization, but indeed by the level of liquidity. Distinguishing between the different types of deposits, the results show that the growth of income has stimulated long-term deposits to a greater extent, although the impact of the rising market rates and the development of the payment system mainly influence short-term deposits.

${ }^{32}$ In almost all of the following regressions the $p$-value of the Sargan test is lower than .2 . This is probably due to the comparatively large set of instrumental variables used in the GMM estimations. Reducing the number of instruments generally produces unsatisfactory results, such as a negative sum of the coefficients of the control variables. Obviously, the dynamic structure of the model is relatively complex and can, therefore, only be adequately captured by a rich set of instruments Nevertheless, the AR test do not indicate a misspecification. The standard errors have been computed from heteroscedastic-consistent matrix (Robust-White procedure).

${ }^{33}$ The approach followed in models 1 to 4 is based on the assumption that we can capture the distributional effects of monetary policy according to the different bank-specific characteristics. In order to check the robustness of the direct effect of interest rate, $g d p$, prices and risk, we also estimate a second model without the interaction term (results not shown). In both cases the results are very similar.

${ }^{34}$ Although the higher use of ATMs for cash withdrawals initially tends to increase the use of cash, in the long run it reduces the inventory of cash needed to be idle (which, ceteris paribus, will expand loanable funds). This result is based upon the fact that ATMs are more frequently visited (they are available 24 hours, 365 days) to withdraw smaller amounts of cash than they were in the past when cash was only withdrawn over the counter
} 
by the most solvent banks, have benefited most from the evolution of the payment network to expand their loan supply. These are the banks that have widely developed their ATM networks, and liquidate and compensate the bulk of operations through electronic payment instruments ${ }^{35}$.

The increase in the cost of taking more interbank resources (proxied by mpi) has a negative and significant effect on the growth of bank lending. Nonetheless, the magnitude of this coefficient shows that the effect of the tightening of monetary conditions for periods greater than one year does not appear to be relevant ${ }^{36}$. As shown in tables A1 and A2 in the Appendix A, the limited magnitude of this impact (between $.2-.4$ per cent by a 1 per cent increase in the monetary policy indicator) may be tentatively explained by the high level of debt of the Spanish families during the 1990s, and by the favourable environment of growth existing over that decade (Bank of Spain, 2002). When the endogenous variable is "loans plus loan commitments", the tightening is markedly more severe. These results suggest that the adjustment of loan demands, especially firms, occurs by resorting less to loan commitments, in light of the greater flexibility that this instrument presents compared with traditional lending (Saunders and Allen, 2004).

As for the impact of the macroeconomic context, as expected, the long-term elasticity of the $g d p$ is always positive and statistically significant. At the same time, the response of loan to inflation, even if negative and significant, is limited. This is due to the notorious contraction of prices under the Spanish economy during the 1990s, especially during the second half of the decade, after the change in monetary policy adopted by the Bank of Spain in 1995. Finally, the variable risk, although positive, does not present a homogeneous pattern of significance. The impact of risk is statistically significant only when we include loan commitments in the loan definition. The fact that an increase in nonperforming loans does not result in a reduction of traditional lending must be explained by the

from bank branches. This is an empirical regularity in surveys and empirical papers on the use of cash and ATMs (e.g. Humphrey, 2004 for the US; and Carbó, Humphrey and López del Paso, 2007 for Spain).

${ }^{35}$ We re-run the different regressions by substituting the non-cash payments indicator previously defined for the ratio "value of non-cash payment/(value of non-cash payments + value of cash withdrawals from ATMs)". In all cases, the results (not shown) are similar.

${ }^{36}$ The regression analysis was performed substituting the three-month interbank interest rate by the estimation of reaction function of the Central Bank, within a VAR-framework similar to Bernanke and Mihov (1998). Here the interest rate shocks are interpreted as the exogenous interest rate component. They indicate the deviation of the 
existence of long-term consolidated relationships between the banks and their clients (Berlin and Mester, 1998) $)^{37}$.

If one looks at the coefficients of the interaction of $m p i$ with bank characteristics, it can be observed that the interaction with size is statistically significant only when lending is defined in a broad sense. This result is in line with Hernando and Martínez-Pagés (2003) and Ehrmann et al. $(2003)^{38}$. On this basis, the supply of loan commitments of the smaller banks is more sensitive to variations in the market rate. All the evidence, then, suggests that small institutions adjust their loan supply preferentially through off-balance sheet transactions, in such a way that the reinforcement of this line of business means that loan tightening is less affected by rising market rates. Similar conclusions are drawn when the degree of capitalisation is included as a second bank characteristic. The analysis by bank size indicates that banks with a greater volume of assets also present a greater level of solvency. Finally, as the bank-lending channel theory predicts, the Spanish banks appear to have reduced the impact of monetary shocks by selling liquid assets. The coefficients corresponding to this indicator are positive and highly significant. The impact of an increase of one percentage point in the monetary policy indicator on loans decreases on average by .104 (.260 when we employ loans plus loans commitments) when the liquidity ratio of a bank increased by one percentage point ${ }^{39}$. This finding implies that, in periods of a restrictive monetary policy, an average borrower from a less liquid bank tends to experience a sharper decline in lending than an average customer of a more liquid bank.

actual interest rate from the estimated Central Bank reaction (Taylor, 1993). In this case, the results (not shown) are quite similar to those obtained using a synthetic interest rate.

37 The short-term coefficient analysis indicates that signs do not vary as the number of lags in the variable increases. Therefore, the hypothesis derived from the fulfillment of the financial balance channel cannot be confirmed.

38 The discrepancy between the results obtained and those expected may result from compensation of the negative effect associated with the greater informative asymmetries with the positive effect derived from a greater degree of liquidity and capitalization on the part of the smaller banks (Kashyap and Stein, 1995). There is also a possible problem of identification, as in the computation of the coefficients of interaction, equal elasticity of the loan demand with respect to the type of interest rate for all banks in the sample is implicitly assumed, when in fact there is usually a variety due to client heterogeneity and the nature of the bank-client link (Loupias et al., 2003).

${ }^{39}$ In order to capture the influences of institutional and regulatory factors and of the level of access to interbank market, we define alternative liquidity indicators. A first alternative indicator is defined by deducting cash and the deposits in Central Banks from our initial definition (liq). A second indicator is defined by also deducting interbank deposits. Both alternative indicators produce similar results (not shown). A third possibility is the use of two indicators simultaneously: on one hand, the sum of cash and deposits in Central Banks, Government 
We also study the dynamics of the regression equation which permits to disentangle the "pure" effects of non-cash payments on loan supply from other effects (not shown). For this purpose, we depart from the point estimates of the coefficients in Table 2. Additionally, we assume that the paths of the other variables (i.e. set of macroeconomic variables, bank-specific characteristics) are held constant at their steady state path. Given that the variables are taken in first differences, this is equivalent to setting the parameter corresponding to the cyclical indicators and the interaction coefficients between the monetary policy indicator and the bank characteristics (size, capitalization and liquidity) equal to zero. We find that a one percentage rise in the share of non-cash payments in total payments value leads to an increase of $.157(.267)$ in the value of loans (loans plus loans commitments) supplied by an average bank. Employing a similar scheme, we can estimate the economic impact of a simultaneous change in the retail payment structure and the cyclical economic variables on loans. In this case, the impact of a one percentage point increase in noncash on $\Delta$ loan (Aloancom) is equivalent to a .77 (.95) percentage point increase in $g d p$, or alternatively, a $3.06(3.13)$ percentage points decrease in $c p i$.

As an additional robustness check we also examine the evolution of the estimated loan supply relationship over time in order to infer if the effects on non-cash payments are significant for the entire sample period. This test involves an OLS cross-section estimation of equation (15) for every year. The results are shown in Tables B1 and B2 of Appendix B using both loan and loancom (loans and loan commitments) as the dependent variables, respectively. Non-cash payments are found to be significantly and positively related to bank loans in all years. While the estimated parameters of noncash do not seem to follow a clear upward or downward trend over time, the marginal effects they account for are found to be one of the highest among the posited set of explanatory variables, thereby illustrating the important role that non-cash payments have played in loan supply by Spanish banks.

bonds and other securities, and, on the other, interbank deposits. In this case, the results (not shown) indicate that both components are significant, although the coefficient of the former is higher. 


\section{Conclusions}

There are substantial differences on the structure of the retail payment systems across European countries. The effects of disparities in the retail payment systems affect the operative efficiency of the mechanisms of monetary policy transmission. Furthermore, the greater or lesser adoption of non-cash instruments can alter the magnitude of the effects of variations in loan supply. Banks can increase their deposits by a more extensive use of ATMs, credit cards at the points of sale, giros, and credit transfers. All three allow banks to cushion the effects of tightened monetary conditions upon the bank-loan supply.

We have examined the Spanish case to analyse how the evolution of the retail payment system can modify deposit demand behaviour and, therefore, bank loan supply. The development of the retail payment system has helped Spanish banks increase their non-bank deposits and, hence, their loan supply. This expansive effect has relied, to a much greater extent, upon the implementation and acceptance of credit cards, and the generalized practice of cash withdrawals from ATMs, than on the development of the instruments used in the liquidation of large-scale payments such as bank giros. The relatively low cost of the instruments used in the liquidation of "face to face" transactions, together with the convenience and security of the ATMs and point of sale terminals, contribute to a higher level of efficiency in channelling economic resources. The influence of this development on the banking business is largely determined by the banks' balance sheet structure. Larger institutions -usually with higher liquidity- seem to benefit of the evolution of the payment network to expand their credit supply to a larger extent. Those institutions with high capitalization also take advantage of the payments development to expand their loan supply.

Although the tightening of monetary conditions have affected banks' loan supply, the impact in Spain appears to be much lower that of the rest of the European countries, largely due to the pressure exerted by demand, associated with the high level of debt observed in Spanish households. This dimension does not seem to have heightened the degree of response of banks facing changes in 
monetary policy, just as the theory of bank-lending channel predicts, except when credit is understood in a broad sense. 


\section{References}

Álvarez, J., 1999, Dynamics and seasonality in quarterly panel data: An analysis of earnings mobility in Spain, CEMFI Working Papers n 9914.

Altunbas, Y., O. Fazylov and P. Molyneux, 2002, Evidence on the bank lending channel in Europe, Journal of Banking and Finance 26, 2093-2110.

Arellano, M. and O. Bover, 1995, Another look at the IV estimation of error components model, Journal of Econometrics 68, 29-62.

Arellano, M. and S. Bond, 1991, Some test specifications for panel data: Monte Carlo evidence and an application to employment equations, The Review of Economic Studies 58, 277-297.

Attanasio, O. P., Goldberg, P. K., and E. Kyriazidou, 2004, Credit Constraints in the Market for Consumer Durables: Evidence from Micro Data of Car Loans, NBER Working Paper.

Ausubel, L.M., 1991, The Failure of Competition in the Credit Card Market," American Economic Review, 81, 50-81.

Bank of Spain, 2002, Annual Report, Bank of Spain, Madrid.

Berlin, M. and L. Mester, 1998, On the profitability and cost of relationship lending, Journal of Banking and Finance 22, 873-897.

Bernanke, B. and A. Blinder, 1988, Credit, Money, and Aggregate Demand, American Economic Review 78, 435-439.

Bernanke, B. and A. Blinder, 1992, The federal Funds Rate and channels of monetary transmission, American Economic Review 78, 901-921.

Bernanke, B. and M. Gertler, 1995, Inside the black box: The credit channel of monetary policy transmission, The Journal of Economic Perspectives 9, 27-48.

Bernanke, B. and I. Mihov, 1998, Measuring Monetary Policy, Quarterly Journal of Economics 113, 909-932.

Blundell, R. and S. Bond, 1998, Initial condition and moments restrictions in dynamic panel data models, Journal of Econometrics 87, 115-143.

Boeschoten, W., 1992, Currency use and payment patterns (Kluwer Academic Publications, Amsterdam).

Bond, S., 2002, Dynamic panel data models: A guide to micro data methods and practice, The Institute for Fiscal Studies, Department of Economics, CEMMAP, Working Paper CWP 09/02.

Borio, C., C. Furfine, and P. Lowe, 2001, Procyclicality of the financial system and financial stability: Issues and policy options, BIS Working Papers $n^{\circ} 1$.

Brito, D. L. and P. R. Hartley, 1995, Consumer Rationality and Credit Cards, The Journal of Political Economy, 103, 400-433.

Calem, P. S. and L. J. Mester, 1995, Consumer Behavior and the Stickiness of Credit Card Interest Rates, American Economic Review, 85, 1327-1336. 
Cargill, T. F. and J. Wendel, 1996, Bank Credit Cards: Consumer Irrationality versus Market Forces, The Journal of Consumer Affairs, 30, 373-389.

Carbó Valverde, S., Humphrey, D. and R. López del Paso, 2007, Opening the Black Box: Finding the Source of Cost Inefficiency, Journal of Productivity Analysis, 27(3), 209-220.

Carroll, C., 1992, The Buffer-Stock Theory of Saving: Some Macroeconomic Evidence, Brookings Papers on Economic Activity, 2: 61-156.

Cottarelli, C. and A. Kourelis, 1994, Financial structure, bank lending rates and the transmission mechanism of monetary policy, Staff Paper International Monetary Fund December, 587-633.

Deaton, A., 1991, Saving and Liquidity Constraints, Econometrica, 59, 1221-1248.

Drehmann, M., C. Goodhart and M. Krueger, 2002, The challenges facing currency usage: will the traditional transactions medium be able to resist competition from the new technologies?, Economic Policy, 34, 193-227.

Diamond, D., 1984, Financial intermediation and delegated monitoring, Review of Economic Studies 54, 393-414.

Ehrmann, M., L. Gambacorta, J. Martínez-Pagés, P. Sevestre and A. Worms, 2003, Financial system and the role of banks in monetary policy transmission in the euro area." Oxford Review of Economic Policy 19, 58-72.

European Central Bank, 2001, Payment and securities settlement systems in the European Union. (European Central Bank, Frankfurt).

European Central Bank, 2003, Towards a Single Euro Payment Area-progress report (European Central Bank Frankfurt).

Fase, M., 1995, The demand for commercial loans and the lending rate, European Economic Review 39, 99-115.

Fase, M. and G. De Bondt, 2000, Institutional environment and monetary transmission in the euroarea: A cross country view, Revue de la Banque 64, 149-155.

Favero, C. F. Giavazzi and L. Flabbi, 1999, The transmission mechanism of monetary policy in Europe: Evidence from banks’ balance sheets, NBER Working Paper $\mathrm{n}^{\circ} 7231$.

Gertler, M., 1988, Financial structure and aggregate economic activity: An overview, Journal of Money, Credit and Banking 20, 559-588.

Goodfried, M., 1995, The impact of monetary policy on bank balance sheets, Carnegie Rochester Conference Series on Public Policy 42, 197-202.

Gross, D. and N. S. Souleles, 2002, Do Liquidity Constraints and Interest Rates Matter for Consumer Behavior? Evidence from Credit Card Data, Quarterly Journal of Economics, 117, 149-185.

Hernando, I. and J. Martínez-Pagés, 2003, Is there a bank lending channel of monetary policy in Spain, in Angeloni, I., Kashyap, A. and B. Mojon (eds.), Monetary Policy Transmission in the Euro area, Cambridge University Press, 284-296. 
Ho, T. and A. Saunders, 1981, The determinants of bank interest margins: Theory and empirical evidence, Journal of Financial and Quantitative Analysis 16, 581-600.

Humphrey, D., 2004, Replacement of cash by cards in US consumer payments, Journal of Economics and Business 56, 21-225.

Humphrey, D., A. Kaloudis and G. Owre, 2004, The future of cash: falling legal use and implications for government policy, International Financial Markets, Institution and Money 14, 221233.

Hyllerberg, S., 1992, The X-11 method" in Hyllerberg, S. (ed.) Modelling Seasonality (Oxford University Press).

Jarayatne, J. and P. Strahan, 1996, The finance-growth nexus: Evidence from bank branch desregulation, Quarterly Journal of Economics 111, 639-670.

Kashyap, A. and J. Stein, 1994, Monetary Policy and bank lending, in Mankiw G. (ed.), Monetary Policy, (University of Chicago Press).

Kashyap, A. and J. Stein, 1995, The impact of monetary policy on bank balance sheets, Carnegie Rochester Conference Series on Public Policy 42, 151-195.

Kashyap, A. and J. Stein, 2000, What do a million observations on banks say about the transmission of monetary policy?, American Economic Review 90, 407-428.

Kishan, R. and T. Opiela, 2000, Bank size, bank capital and the bank lending channel, Journal of Money, Credit, and Banking 32, 121-141.

Lang, G. and P. Welzel, 1999, Merger among German cooperatives banks: A panel stochastic frontier analysis, Small Business Economics 13, 273-286.

Loupias, C., Savignac, F. and P. Sevestre (2003), Is there a bank-lending channel in France? Evidence from bank panel data, in Angeloni, I., Kashyap, A. and B. Mojon (eds.), Monetary Policy Transmission in the Euro area, Cambridge University Press, 297-308.

Ludvigson, S., 1999, Consumption and Credit: A Model of Time-Varying Liquidity Constraints," The Review of Economics and Statistics, 8, 434-447

Mishra, S.K. (2004), Median as a weighted arithmetic mean of all sample observations, Economic Bulletin, 3, 1-18.

Morgan, D., 1998, The credit effects of monetary policy: Evidence using loan commitments, Journal of Money, Credit, and Banking 30, 102-118.

Paroush, J. and D. Ruthenberg, 1986, Automated teller machines and the share of demand deposits in the money supply: The Israeli experience, European Economic Review 30, 1207-1215.

Peek, J., and Rosengren, E., 1995, Bank lending and the transmission of monetary policy, in Peek, J. and Rosengren, P. (eds) Is bank lending important for the transmission of monetary policy? (Federal Reserve Bank of Boston Conference Series n ${ }^{\circ} 39$, Boston) .

Rysman, M., 2007, An empirical analysis of credit card usage, Journal of Industrial Economics, $55,1-36$. 
Saunders, A. and L. Allen, 2004, Incorporating systemic influences into risk measurement: A survey of the Literature, Journal of Financial Services Research (forthcoming).

Schneider, F., 1986, Estimating the size of Danish shadow economy using the currency demand approach: An attempt, Scandinavian Journal of Economics 88, 70-89.

Sellon, G., 2002, The changing U.S. financial system: Some implications for the monetary transmission mechanism, Federal Reserve Bank of Kansas City Economic Review First Quarter, 5-35.

Stein, J., 1998, An adverse selection model of bank asset and liability management with implication for the transmission of monetary policy, Rand Journal of Economics 29, 466-486.

Taylor, J., 1993, Discretion versus policy rules in practice, Carnegie Rochester Conference Series on Public Policy 39, 195-214.

Viren, M., 1992, Financial innovations and currency demand: some new evidence, Empirical Economics 17, 451-461.

Worms, A., 2003, The reaction of bank lending to monetary policy measures in Germany, Journal of Applied Economics and Economic Policy 30, 179-198.

Zilberfarb, B., 1989, The effect of automated teller machines on demand deposits: An empirical analysis, Journal of Financial Services Research 2, 49-57. 
Table 1: Development of the Retail Payment System in Spain and in the EMU (In percentage)

\begin{tabular}{lcccccc}
\hline \hline & $\mathbf{1 9 9 2}$ & $\mathbf{1 9 9 4}$ & $\mathbf{1 9 9 6}$ & $\mathbf{1 9 9 8}$ & $\mathbf{2 0 0 0}$ & Change \\
\hline \hline $\begin{array}{l}\text { Spain } \\
\text { Cash/GDP }\end{array}$ & 10.2 & 11.1 & 9.9 & 9.6 & 8.9 & -12 \\
Value of transaction with & & & & & & \\
Non-cash instruments /GDP & 2.35 & 1.94 & 3.92 & 3.28 & 3.46 & 47 \\
Transferable Deposits/ GDP & 33.2 & 33.4 & 30.2 & 37.3 & 43.5 & 31 \\
Loans/GDP & 54.9 & 59.8 & 70.8 & 83.2 & 94.6 & 72 \\
Operating Cost/Total Assets & 3.0 & 2.7 & 2.4 & 2.2 & 1.9 & -37 \\
EMU* & & & & & & \\
Cash/GDP & 5.5 & 5.6 & 5.4 & 5.5 & 5.4 & -2 \\
Value of transaction with & & & & & & \\
Non-cash instruments /GDP & 7.00 & 7.87 & 7.61 & 8.14 & 8.34 & 19 \\
Transferable Deposits/ GDP & 20.6 & 21.6 & 21.6 & 24.3 & 28.5 & 38 \\
Loans/GDP & 85.2 & 88.7 & 91.3 & 102.2 & 115.4 & 35 \\
Operating Cost/Total Assets & 1.9 & 1.7 & 1.6 & 1.5 & 1.6 & -15 \\
\hline \hline Sources: ECB (Blue Book, Addendum 2003) and Carbó, Humphrey and López del Paso (2007) from Bureau Van Dijk Bankscope \\
database. \\
*Greece is not included due to missing data on most variables considered. & & & & \\
\hline \hline
\end{tabular}


Table 2: Impact of the development of the retail payment system on loan and loancom.

\begin{tabular}{|c|c|c|}
\hline \multirow[t]{2}{*}{$\begin{array}{l}\text { Long-term } \\
\text { coefficients }\end{array}$} & \multicolumn{2}{|c|}{$\begin{array}{c}\text { Model } 1 \\
\text { Dependent variable }\end{array}$} \\
\hline & loan & loancom \\
\hline gdp & $\begin{array}{l}.272 * * \\
(.262)\end{array}$ & $\begin{array}{l}.284 * * \\
(.242)\end{array}$ \\
\hline cpi & $\begin{array}{c}-.067 * * \\
(.023)\end{array}$ & $\begin{array}{c}-.062^{* *} \\
(.092)\end{array}$ \\
\hline risk & $\begin{array}{l}.011 \\
(.017)\end{array}$ & $\begin{array}{l}.032^{*} \\
(.015)\end{array}$ \\
\hline mpi & $\begin{array}{c}-.129 * * \\
(.030)\end{array}$ & $\begin{array}{c}-.218^{* *} \\
(.016)\end{array}$ \\
\hline noncash & $\begin{array}{l}.219 * \\
(.038)\end{array}$ & $\begin{array}{l}.281 * * \\
(.138)\end{array}$ \\
\hline$m p i \cdot t a$ & $\begin{array}{l}.002 \\
(.007)\end{array}$ & $\begin{array}{l}.012^{*} \\
(.007)\end{array}$ \\
\hline mpi $\cdot$ cap & $\begin{array}{c}.062 \\
(.298)\end{array}$ & $\begin{array}{l}.098 * \\
(.442)\end{array}$ \\
\hline$m p i \cdot l i q$ & $\begin{array}{l}.104 * * \\
(.130)\end{array}$ & $\begin{array}{l}.260 * * \\
(.372)\end{array}$ \\
\hline noncash ta & $\begin{array}{c}2.302 * * \\
(.964)\end{array}$ & $\begin{array}{c}2.853 * * \\
(.453)\end{array}$ \\
\hline noncash cap & $\begin{array}{c}2.285 * * \\
(.298)\end{array}$ & $\begin{array}{c}2.664 * * \\
(.244)\end{array}$ \\
\hline noncash tiq & $\begin{array}{c}1.478 * * \\
(.301)\end{array}$ & $\begin{array}{c}2.603 * * \\
(.728)\end{array}$ \\
\hline$A R 1$ & .000 & .000 \\
\hline$A R 2$ & .147 & .143 \\
\hline Sargan Test & .237 & .324 \\
\hline
\end{tabular}

Notes: **** denotes significance at 1 and $5 \%$ levels. Number of observations: 4,572. Number of banks: 127. Estimation by GMM-system estimator using the robust two step method. Sargan test is a test of over-identifying restrictions (p-value reported), distributed as chi-squared under the null of instruments validity. $\mathbf{M}_{j}$ is a test of $j$ thorder serial correlation in the first-differenced residuals. These are both distributed as standard normal under the null hypothesis. Asymptotic robust standard errors reported in parenthesis. Standard errors for the long run effect have been approximated with the delta method which expands a function of a random variable with a one-step Taylor expansion.

Variable definition: loan: total loans; loancom: total loans plus loan commitments; gdp: Gross Domestic Product; cpi: Consumer price index; risk: level of risk; mpi: monetary policy indicator; noncash: value of non cash payments; ta: size; cap: degree of capitalization: liq: degree of liquidity. 


\section{Appendix A: Results for Models 2, 3 and 4}

Table A1: Impact of the development of the retail payment system on loan.

\begin{tabular}{|c|c|c|c|}
\hline $\begin{array}{l}\text { Long-term } \\
\text { coefficients }\end{array}$ & $\begin{array}{c}\text { Model } 2 \\
b c: t a\end{array}$ & $\begin{array}{l}\text { Model 3 } \\
\text { bc: } \text { cap }\end{array}$ & $\begin{array}{c}\text { Model } 4 \\
\text { bc: } \text { liq }\end{array}$ \\
\hline$g d p$ & $\begin{array}{l}.232 * \\
(.101)\end{array}$ & $\begin{array}{l}.294 * * \\
(.114)\end{array}$ & $\begin{array}{l}.262 * * \\
(.092)\end{array}$ \\
\hline cpi & $\begin{array}{c}-.029 * * \\
(.011)\end{array}$ & $\begin{array}{c}-.090 * * \\
(.026)\end{array}$ & $\begin{array}{c}-.030^{* * *} \\
(.008)\end{array}$ \\
\hline risk & $\begin{array}{l}.014 \\
(.012)\end{array}$ & $\begin{array}{c}.033 \\
(.015)\end{array}$ & $\begin{array}{c}.017 \\
(.012)\end{array}$ \\
\hline mpi & $\begin{array}{c}-.342 * * \\
(.053)\end{array}$ & $\begin{array}{l}-.337 * \\
(.161)\end{array}$ & $\begin{array}{c}-.366^{* * *} \\
(.017)\end{array}$ \\
\hline noncash & $\begin{array}{l}.080^{*} \\
(.041)\end{array}$ & $\begin{array}{l}.128^{*} \\
(.121)\end{array}$ & $\begin{array}{l}.067 * * \\
(.087)\end{array}$ \\
\hline$m p i \cdot b c$ & $\begin{array}{l}.005 \\
(.012)\end{array}$ & $\begin{array}{l}.156 \\
(.757)\end{array}$ & $\begin{array}{l}.043^{*} \\
(.412)\end{array}$ \\
\hline noncash bc & $\begin{array}{c}3.294 * * \\
(.822)\end{array}$ & $\begin{array}{c}1.169 * * \\
(.166)\end{array}$ & $\begin{array}{c}1.107 * * \\
(.432)\end{array}$ \\
\hline$A R 1$ & .000 & .000 & .000 \\
\hline$A R 2$ & .182 & .141 & .132 \\
\hline Sargan Test & .169 & .163 & .299 \\
\hline
\end{tabular}

Notes: $* * / *$ denotes significance at 1 and $5 \%$ levels. Number of observations: 4,572. Number of banks: 127. Estimation by GMM-system estimator using the robust two step method. Sargan test is a test of over-identifying restrictions ( $\mathrm{p}$-value reported), distributed as chi-squared under the null of instruments validity. $\mathbf{M}_{j}$ is a test of $j$ th-order serial correlation in the first-differenced residuals. These are both distributed as standard normal under the null hypothesis. Asymptotic robust standard errors reported in parenthesis. Standard errors for the long run effect have been approximated with the delta method which expands a function of a random variable with a one-step Taylor expansion.

Variable definition: loan: total loans; loancom: total loans plus loan commitments; gdp: Gross Domestic Product; cpi: Consumer price index; risk: level of risk; mpi: monetary policy indicator; noncash: value of non cash payments; ta: size; cap: degree of capitalization: liq: degree of liquidity. 
Table A2: Impact of the development of the retail payment system on loancom.

\begin{tabular}{|c|c|c|c|}
\hline $\begin{array}{l}\text { Long-term } \\
\text { coefficients }\end{array}$ & $\begin{array}{c}\text { Model } 2 \\
\text { bc: } t a \\
\end{array}$ & $\begin{array}{l}\text { Model } 3 \\
\text { bc: } \text { cap }\end{array}$ & $\begin{array}{c}\text { Model } 4 \\
\text { bc: liq }\end{array}$ \\
\hline$g d p$ & $\begin{array}{l}.326^{*} \\
(.256)\end{array}$ & $\begin{array}{l}.301 * * \\
(.379)\end{array}$ & $\begin{array}{l}.283^{*} * \\
(.246)\end{array}$ \\
\hline cpi & $\begin{array}{c}-.106 * * \\
(-035)\end{array}$ & $\begin{array}{l}-.051 * \\
(.102)\end{array}$ & $\begin{array}{c}-.062 * * \\
(.021)\end{array}$ \\
\hline risk & $\begin{array}{c}.058 \\
(.041)\end{array}$ & $\begin{array}{l}.097 \\
.059)\end{array}$ & $\begin{array}{l}.066^{*} \\
(.043)\end{array}$ \\
\hline mpi & $\begin{array}{c}-0.464 * * \\
(.148)\end{array}$ & $\begin{array}{c}-.401 * * \\
(.051)\end{array}$ & $\begin{array}{c}-.399 * * \\
(.058)\end{array}$ \\
\hline noncash & $\begin{array}{l}.187 * * \\
(.082)\end{array}$ & $\begin{array}{l}.175^{* *} \\
(.215)\end{array}$ & $\begin{array}{l}.948 * * \\
(.302)\end{array}$ \\
\hline$m p i \cdot b c$ & $\begin{array}{l}.076^{*} \\
(.028)\end{array}$ & $\begin{array}{l}.284^{*} \\
(.122)\end{array}$ & $\begin{array}{l}.065^{*} \\
(.238)\end{array}$ \\
\hline noncash bc & $\begin{array}{l}2.390^{*} \\
(.429)\end{array}$ & $\begin{array}{c}3.558^{* *} \\
(.136)\end{array}$ & $\begin{array}{c}2.567 * * \\
(.672)\end{array}$ \\
\hline$A R 1$ & .000 & .000 & .000 \\
\hline$A R 2$ & .129 & .215 & .185 \\
\hline Sargan Test & .353 & .142 & .175 \\
\hline
\end{tabular}

Notes: $* * / *$ denotes significance at 1 and $5 \%$ levels. Number of observations: 4,572. Number of banks: 127. Estimation by GMM-system estimator using the robust two step method. Sargan test is a test of over-identifying restrictions (p-value reported), distributed as chi-squared under the null of instruments validity. $\mathrm{M}_{j}$ is a test of $j$ th-order serial correlation in the first-differenced residuals. These are both distributed as standard normal under the null hypothesis. Asymptotic robust standard errors reported in parenthesis. Standard errors for the long run effect have been approximated with the delta method which expands a function of a random variable with a one-step Taylor expansion.

Variable definition: loan: total loans; loancom: total loans plus loan commitments; $g d p$ : Gross Domestic Product; cpi: Consumer price index; risk: level of risk; mpi: monetary policy indicator; noncash: value of non cash payments; ta: size; cap: degree of capitalization: liq: degree of liquidity. 
Appendix B: OLS cross-section regressions

Table B1: Impact of the development of the retail payment system on loan.

\begin{tabular}{|c|c|c|c|c|c|c|c|c|c|}
\hline & 1992 & 1993 & 1994 & 1995 & 1996 & 1997 & 1998 & 1999 & 2000 \\
\hline$g d p$ & $\begin{array}{l}.258 * * \\
(.210)\end{array}$ & $\begin{array}{l}.157 * * \\
(.157)\end{array}$ & $\begin{array}{l}.398 * * \\
(.223)\end{array}$ & $\begin{array}{l}.401 * * \\
(.148)\end{array}$ & $\begin{array}{l}.103 * * \\
(.147)\end{array}$ & $\begin{array}{l}.326^{* *} \\
(.109)\end{array}$ & $\begin{array}{l}.174 * * \\
(.199)\end{array}$ & $\begin{array}{l}.221 * * \\
(.215)\end{array}$ & $\begin{array}{l}.200 * * \\
(.191)\end{array}$ \\
\hline cpi & $\begin{array}{c}.077 * * * \\
(.018)\end{array}$ & $\begin{array}{c}-.065^{* *} \\
(.021)\end{array}$ & $\begin{array}{c}-.089^{* *} * \\
(.022)\end{array}$ & $\begin{array}{c}.061 * * \\
(.021)\end{array}$ & $\begin{array}{c}-.049 * * \\
(.016)\end{array}$ & $\begin{array}{c}-.012^{* *} \\
(.009)\end{array}$ & $\begin{array}{c}-.065^{* *} * \\
(.024)\end{array}$ & $\begin{array}{c}.059 * * \\
(.012)\end{array}$ & $\begin{array}{c}.073 * * \\
(.012)\end{array}$ \\
\hline risk & $\begin{array}{c}.009 \\
(.010)\end{array}$ & $\begin{array}{c}.012 \\
(.021)\end{array}$ & $\begin{array}{c}.012 \\
(.021)\end{array}$ & $\begin{array}{c}.001 \\
(.013)\end{array}$ & $\begin{array}{c}.003 \\
(.021)\end{array}$ & $\begin{array}{c}.007 \\
(.009)\end{array}$ & $\begin{array}{c}.004 \\
(.021)\end{array}$ & $\begin{array}{c}.007 \\
(.012)\end{array}$ & $\begin{array}{c}.008 \\
(.014)\end{array}$ \\
\hline mpi & $\begin{array}{c}-.106^{* * *} \\
(.029)\end{array}$ & $\begin{array}{c}-.149 * * \\
(.042)\end{array}$ & $\begin{array}{c}-.258 * * \\
(.034)\end{array}$ & $\begin{array}{c}-.178 * * \\
(.024)\end{array}$ & $\begin{array}{c}-.147 * * \\
(.021)\end{array}$ & $\begin{array}{c}-.178^{* *} \\
(.021)\end{array}$ & $\begin{array}{c}-.159 * * \\
(.012)\end{array}$ & $\begin{array}{c}-.136 * * \\
(.021)\end{array}$ & $\begin{array}{c}-.101 * * \\
(.025)\end{array}$ \\
\hline noncash & $\begin{array}{l}.319 * \\
(.042)\end{array}$ & $\begin{array}{l}.249 * \\
(.041)\end{array}$ & & $\begin{array}{l}.278^{*} \\
(.025)\end{array}$ & $\begin{array}{l}.149^{*} \\
(.014)\end{array}$ & $\begin{array}{l}.369 * \\
(.038)\end{array}$ & $\begin{array}{l}.125 * \\
(.041)\end{array}$ & $\begin{array}{l}.258^{*} \\
(.041)\end{array}$ & $\begin{array}{l}.213 * \\
(.025)\end{array}$ \\
\hline$m p i \cdot t a$ & $\begin{array}{c}.003 \\
(.006)\end{array}$ & $\begin{array}{c}.005 \\
(.009)\end{array}$ & $\begin{array}{c}.009 \\
(.007)\end{array}$ & $\begin{array}{c}.006 \\
(.007)\end{array}$ & $\begin{array}{c}.001 \\
(.006)\end{array}$ & $\begin{array}{c}.004 \\
(.009)\end{array}$ & $\begin{array}{c}.001 \\
(.004)\end{array}$ & $\begin{array}{c}.001 \\
(.006)\end{array}$ & $\begin{array}{c}.007 \\
(.006)\end{array}$ \\
\hline Mpi.cap & $\begin{array}{c}.051 \\
(.198)\end{array}$ & $\begin{array}{c}.075 \\
(.223)\end{array}$ & $\begin{array}{c}.078 \\
(.158)\end{array}$ & $\begin{array}{c}.042 \\
(.278)\end{array}$ & $\begin{array}{c}.013 \\
(.200)\end{array}$ & $\begin{array}{c}.057 \\
(.212)\end{array}$ & $\begin{array}{c}.058 \\
(.223)\end{array}$ & $\begin{array}{c}.059 \\
(.259)\end{array}$ & $\begin{array}{c}.058 \\
(.225)\end{array}$ \\
\hline mpi.liq & $\begin{array}{l}.112^{* * *} \\
(.069)\end{array}$ & $\begin{array}{l}.139 * * \\
(.125)\end{array}$ & $\begin{array}{l}.258^{* *} \\
(.100)\end{array}$ & $\begin{array}{l}.198^{* * *} \\
(.125)\end{array}$ & $\begin{array}{l}.236^{* *} * \\
(.115)\end{array}$ & $\begin{array}{l}.136^{* * *} \\
(.114)\end{array}$ & $\begin{array}{l}.102^{* *} \\
(.125)\end{array}$ & $\begin{array}{l}.114 * * \\
(.123)\end{array}$ & $\begin{array}{l}.119^{* *} \\
(.125)\end{array}$ \\
\hline Noncash ta & $\begin{array}{c}2.598 * * \\
(.845)\end{array}$ & $\begin{array}{c}3.162 * * \\
(.786)\end{array}$ & $\begin{array}{c}2.598 * * \\
(.658)\end{array}$ & $\begin{array}{c}3.021 * * \\
(.879)\end{array}$ & $\begin{array}{c}2.479 * * * \\
(.459)\end{array}$ & $\begin{array}{c}2.478 * * \\
(.874)\end{array}$ & $\begin{array}{c}2.458 * * \\
(.879)\end{array}$ & $\begin{array}{c}2.587 * * \\
(.969)\end{array}$ & $\begin{array}{c}2.587 * * \\
(.879)\end{array}$ \\
\hline noncash cap & $\begin{array}{c}3.002 * * \\
(.195)\end{array}$ & $\begin{array}{c}1.458^{* * *} \\
(.129)\end{array}$ & $\begin{array}{c}2.369 * * \\
(.221)\end{array}$ & $\begin{array}{c}2.423 * * \\
(.268)\end{array}$ & $\begin{array}{c}2.479 * * \\
(.223)\end{array}$ & $\begin{array}{c}2.478 * * * \\
(.221)\end{array}$ & $\begin{array}{c}2.358 * * \\
(.247)\end{array}$ & $\begin{array}{c}2.211^{* * *} \\
(.221)\end{array}$ & $\begin{array}{c}2.479 * * \\
(.212)\end{array}$ \\
\hline Noncash liq & $\begin{array}{c}1.574 * * \\
(.247)\end{array}$ & $\begin{array}{c}1.987 * * \\
(.209)\end{array}$ & $\begin{array}{c}1.598 * * \\
(.207)\end{array}$ & $\begin{array}{c}1.436 * * \\
(.257)\end{array}$ & $\begin{array}{c}1.578 * * \\
(.206)\end{array}$ & $\begin{array}{c}1.578^{* *} \\
(.221)\end{array}$ & $\begin{array}{c}1.498 * * \\
(.258)\end{array}$ & $\begin{array}{c}1.369 * * \\
(.302)\end{array}$ & $\begin{array}{c}1.578 * * \\
(.298)\end{array}$ \\
\hline$R^{2}$ & 0.75 & 0.78 & 0.85 & 0.71 & 0.81 & 0.85 & 0.69 & 0.87 & 0.92 \\
\hline
\end{tabular}

\begin{tabular}{|c|c|c|c|c|c|c|c|c|c|}
\hline & $110 ?$ & 1009 & & & & & & & \\
\hline & & & & & & & & & \\
\hline$g d p$ & $.274^{*}=$ & $2211^{*}$ & & & & 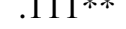 & 367 & * & W \\
\hline & $(.221)$ & $(.201)$ & (.198) & $(.256)$ & $(.189)$ & $(.115)$ & $(.202$ & $(.111)$ & $(.122)$ \\
\hline cpi & $-.058 * *$ & $-.058 * *$ & $-.096^{* *}$ & $-.067 * *$ & $-.058 * *$ & $-.048 * *$ & $-.057 * *$ & $-.047 * *$ & $-.052 * *$ \\
\hline & $(.087)$ & $(.078)$ & $(.087)$ & $(.054)$ & $(.089)$ & $(.078)$ & $(.083$ & $(.012)$ & $(.072)$ \\
\hline risk & $.029 *$ & $.029 *$ & $.023 *$ & $.028 *$ & $.021 *$ & $.025 *$ & $.029 * *$ & $.028 * *$ & $.0262 *$ \\
\hline & $(.013)$ & $(.012)$ & $(.012)$ & $(.009)$ & $(.010)$ & $(.009)$ & $(.012$ & $(.021)$ & $(.115)$ \\
\hline$m p i$ & $-.221 * *$ & $-.217 * *$ & $-.203 * *$ & $-.326 * *$ & $-.198 * *$ & $-.358 * *$ & $-.302 * *$ & $-.574 * *$ & $-.158 * *$ \\
\hline & $(.014)$ & $(.014)$ & $(.011)$ & $(.025)$ & $(.015)$ & $(.014)$ & $(.012$ & $(.022)$ & $(.116)$ \\
\hline noncash & $.278 * *$ & $.296 * *$ & $.265 * *$ & $.407 * *$ & $.212 * *$ & $.325 * *$ & $.368 * *$ & $.357 * *$ & $.371 * *$ \\
\hline & $(.121)$ & $(.125)$ & $(.121)$ & $(.207)$ & $(.125)$ & $(.215)$ & $(.125$ & $(.221)$ & $(.228)$ \\
\hline$m p i \cdot t a$ & $.011 *$ & $.010 *$ & $.010^{*}$ & $.027 *$ & $.011^{*}$ & $.009 *$ & $.010 * *$ & $.010 * *$ & $.122 *$ \\
\hline & $(.006)$ & $(.006)$ & $(.006)$ & $(.009)$ & $(.006)$ & $(.002)$ & $(.004)$ & $(.002)$ & $(.017)$ \\
\hline Mpi.cap & $.087 *$ & $.093 *$ & $.097 *$ & $.112^{*}$ & $.114 *$ & $.129 *$ & $.136 *$ & $.198^{*}$ & $.458^{*}$ \\
\hline & (.469) & $(.369)$ & (.423) & $(.369)$ & $(.339)$ & (.339) & $(.112)$ & $(.382)$ & $(.352)$ \\
\hline mpi.liq & $.257 * *$ & $.278 * *$ & $.259 * *$ & $.368 * *$ & $.369 * *$ & $.221 * *$ & $.247 * *$ & $.230 * *$ & $.390 * *$ \\
\hline & $(.329)$ & $(.369)$ & $(.321)$ & $(.407)$ & $(.254)$ & $(.247)$ & $(.372)$ & $(.252)$ & $(.282)$ \\
\hline noncash ta & $2.987 * *$ & $2.974 * *$ & $2.325 * *$ & $2.369 * *$ & $2.336 * *$ & $4.236 * *$ & $2.789 * *$ & $2.693 * *$ & $2.993 * *$ \\
\hline & $(.423)$ & $(.403)$ & $(.421)$ & $(.412)$ & $(.369)$ & $(.523)$ & $(.123)$ & $(.473)$ & $(.363)$ \\
\hline noncash cap & $2.558^{* * *}$ & $2.556^{* * *}$ & $2.978 * *$ & $2.897 * *$ & $2.498 * *$ & $2.236^{* * *}$ & $2.785^{* *}$ & $2.494 * *$ & $2.794 * *$ \\
\hline & $(.234)$ & $(.223)$ & $(.128)$ & $(.198)$ & $(.215)$ & $(.123)$ & $(.226)$ & $(.194)$ & $(.244)$ \\
\hline noncash liq & $2.547 * *$ & $2.508 * *$ & $2.598 * *$ & $2.709 * *$ & $2.507 * *$ & $3.032 * *$ & $2.782 * *$ & $2.893 * *$ & $2.983 * *$ \\
\hline & $(.712)$ & $(.698)$ & $(.647)$ & $(.628)$ & $(.639)$ & $(.568)$ & $(.621)$ & $(.608)$ & $(.698)$ \\
\hline$R^{2}$ & 0.78 & 0.85 & 0.90 & 0.68 & 0.77 & 0.92 & 0.81 & 0.73 & 0.85 \\
\hline
\end{tabular}

